\title{
Critical Challenges in Enterprise Resource Planning (ERP) Implementation
}

\author{
Sreekumar A. Menon ${ }^{1}$, Marc Muchnick ${ }^{2}$, Clifford Butler ${ }^{3} \&$ Tony Pizur ${ }^{4}$ \\ ${ }^{1}$ Management consultant \& Director R3Synergy Inc., Calgary, Canada \\ ${ }^{2}$ Professor, School of Business \& Technology, Capella University, Minneapolis, US \\ ${ }^{3}$ Chair, SOBT Doctoral Programs, Capella University, Minneapolis, US \\ ${ }^{4}$ Professor, School of Business \& Technology, Capella University, Minneapolis, US \\ Correspondence: Dr. Sreekumar Menon, Business \& Technology Leader \& Director, R3Synergy Inc., Calgary, \\ Canada. E-mail: ask_menon@yahoo.com
}

Received: April 9, 2019

doi:10.5539/ijbm.v14n7p54
Accepted: May 30, 2019

Online Published: June 8, 2019

URL: https://doi.org/10.5539/ijbm.v14n7p54

\begin{abstract}
This research paper explores critical challenges in Enterprise Resource Planning (ERP) implementation based on insights from an exploratory qualitative single case study in the Canadian Oil and Gas Industry. The study was conducted in a Canadian case organization using twenty interviews from members of four project role groups of senior leaders, project managers, project team members, and business users. The study further collected and reviewed project documents from the ERP implementation for triangulation. The research evoked a comprehensive list of sixty critical challenges and out of which, the top twelve challenges discussed in detail were drawn from the responses of participants from all four project role groups. The study findings indicated that critical challenges were significant during ERP implementation. This research is one of first case studies in the Canadian oil and gas industry that focuses on critical challenges in ERP implementation projects.
\end{abstract}

Keywords: Enterprise Resource Planning, ERP, implementation, exploratory qualitative study, critical challenges, critical success factors

\section{Introduction}

The challenges that face global organizations continue to grow increasingly severe and complex. Operating businesses in a highly competitive environment is challenging; to enhance competitiveness and to satisfy customer needs, organizations seek to improve efficiency and agility (Erkan \& Rouyendegh, 2011; Motwani, Subramanian, \& Gopalakrishna, 2005; Stanciu \& Tinca, 2013). Information technology is capable of fundamentally changing the way business works; many organizations use the solution of Enterprise Resource Planning (ERP) systems to improve their competitiveness (Davenport, 1998; Erkan \& Rouyendegh, 2011). ERP systems provide a holistic view of an organization's operations using business intelligence and analytics (Gartner, 2011; Motwani et al., 2005; Parr \& Shanks, 2000). Unfortunately, ERP implementations cost a significant amount of time, money, and professional services, and do not always produce measurable results (Motwani et al., 2005). Therefore, understanding and applying critical challenges during an ERP implementation is crucial for ensuring organizational success (Momoh, Roy, \& Shehab, 2010; Laukkanen, Sarpola, \& Hallikainen, 2007; Stanciu \& Tinca, 2013).

Research findings indicate that despite high costs and lengthy timeframes, ERP implementations do not perform to expectation (Davenport, 1998; Tarn, Yen, \& Beaumont, 2002; Ehie \& Madsen, 2005; Momoh et al., 2010; Stanciu \& Tinca, 2013). This is in part due to a lack of understanding about how to address critical challenges during implementations, which can lead to cancellations, large cost overruns, and project failures (Momoh et al., 2010; Stanciu \& Tinca, 2013). However, potential opportunities exist for global firms to improve ERP implementation success.

\subsection{Dimensions Related to Critical Challenges in ERP Implementations}

The foundational and seminal literature summarizes three dimensions related to critical challenges for this study, as described in Table 1. The critical factors affecting ERP implementations were grouped as human, 
technological, and organizational dimensions, also detailed in Table 1. (Sumner, 2000; Themistocleus et al. 2001; Ehie \& Madsen, 2005; Momoh et al., 2010; Stanciu \& Tinca, 2013).

Table 1. Critical Challenges in ERP implementation as found in the literature

\begin{tabular}{|c|c|c|c|c|c|c|c|}
\hline \multirow[t]{2}{*}{ Dimensions } & \multirow[t]{2}{*}{ Critical challenges } & \multicolumn{6}{|c|}{ Findings } \\
\hline & & Sumner & $\begin{array}{l}\text { Themisto } \\
\text { cleus et } \\
\text { al }\end{array}$ & $\begin{array}{l}\text { Ehie } \\
\text { Madsen }\end{array}$ & $\&$ & $\begin{array}{l}\text { Momoh et } \\
\text { al. }\end{array}$ & $\begin{array}{l}\text { Stanciu \& } \\
\text { Tinca }\end{array}$ \\
\hline Technological & Excessive customization & & $\mathrm{X}$ & & & $\mathrm{X}$ & \\
\hline Organizational & Dilemma of internal integration & & & & & $\mathrm{X}$ & \\
\hline Organizational & $\begin{array}{l}\text { Poor understanding of business implications and } \\
\text { requirements }\end{array}$ & & & & & $\mathrm{X}$ & \\
\hline Human & Lack of change management & & & & & $\mathrm{X}$ & \\
\hline Technological & Poor Data Quality & & & & & $\mathrm{X}$ & \\
\hline Organizational & Misalignment of IT with the business & & & & & $\mathrm{X}$ & \\
\hline Organizational & Hidden costs & & & & & $\mathrm{X}$ & \\
\hline Human & Lack of senior management support & $\mathrm{X}$ & & $\mathrm{X}$ & & $\mathrm{X}$ & $\mathrm{X}$ \\
\hline Organizational & $\begin{array}{l}\text { Failure to redesign business processes to fit the } \\
\text { software }\end{array}$ & $\mathrm{X}$ & & & & & \\
\hline Human & Insufficient training and reskilling / Limited Training & $\mathrm{X}$ & & $\mathrm{X}$ & & $\mathrm{X}$ & $\mathrm{X}$ \\
\hline Human & $\begin{array}{l}\text { Lack of ability to recruit and retain qualified ERP } \\
\text { system developers }\end{array}$ & $\mathrm{X}$ & & & & & \\
\hline Human & Insufficient training of end-users & $\mathrm{X}$ & & & & & \\
\hline Organizational & $\begin{array}{l}\text { Inability to obtain full-time commitment of } \\
\text { 'customers' to project activities and management }\end{array}$ & $\mathrm{X}$ & & & & & \\
\hline Organizational & Lack of integration & $\mathrm{X}$ & $\mathrm{X}$ & & & & \\
\hline Organizational & Lack of a proper management structure & $\mathrm{X}$ & & & & & \\
\hline Human & Insufficient internal expertise & $\mathrm{X}$ & & & & & \\
\hline Human & Lack of a champion & $\mathrm{X}$ & & & & & \\
\hline Human & Lack of business analysts & $\mathrm{X}$ & & & & & \\
\hline Human & Failure to mix internal and external personnel & $\mathrm{X}$ & & & & & \\
\hline Technological & $\begin{array}{l}\text { Failure to emphasize reporting, including custom } \\
\text { report development }\end{array}$ & $\mathrm{X}$ & & & & & \\
\hline Human & Insufficient discipline and standardization & $\mathrm{X}$ & & & & & \\
\hline Human & Ineffective communications & $\mathrm{X}$ & & & & & \\
\hline Technological & Avoid technological bottlenecks & $\mathrm{X}$ & & & & & \\
\hline Organizational & ERP vendor selection & & & & & $\mathrm{X}$ & \\
\hline Human & Internal implementation team & & & & & $\mathrm{X}$ & \\
\hline Human & Project opposition & & & & & $\mathrm{X}$ & \\
\hline Human & user training & & & & & $\mathrm{X}$ & \\
\hline Organizational & Project management principles & & & $\mathrm{X}$ & & & \\
\hline Technological & Feasibility/evaluation of ERP project & & & $\mathrm{X}$ & & & \\
\hline Human & Human resource development & & & $\mathrm{X}$ & & & \\
\hline Organizational & Process re-engineering & & & $\mathrm{X}$ & & & \\
\hline Technological & IT infrastructure & & & $\mathrm{X}$ & & & \\
\hline Human & Consulting services /Client consultation & & & $\mathrm{X}$ & & & \\
\hline Human & Employees resistance to change & & $\mathrm{X}$ & & & & \\
\hline Human & Conflicts with Consultants & & $\mathrm{X}$ & & & & \\
\hline Human & Internal Conflicts & & $\mathrm{X}$ & & & & \\
\hline Human & Conflicts with Vendors & & $\mathrm{X}$ & & & & \\
\hline Organizational & Conflicts with business strategy & & $\mathrm{X}$ & & & & \\
\hline
\end{tabular}

Note. The list is based on the research findings from foundational literature (Sumner, 2000; Themistocleus et al., 2001; Ehie \& Madsen, 2005; Momoh, Roy, \& Shehab, 2010; Stanciu \& Tinca, 2013). 


\subsection{Critical Success Factors in ERP}

Rockart (1979) was the first author to apply the critical success factor approach in the information systems area. The CSF method helped organizations to specify their own critical information needs. Rockart (1979) defined critical success factors as the limited number of areas in which results, if satisfactory, will ensure the organization's successful competitive performance (Esteves \& Pastor, 2001). Researchers of seminal and recent studies have identified several success factors, which are outlined in Table 2.

Table 2. Critical success factors in ERP implementation

\begin{tabular}{|c|c|}
\hline Research Study & Critical Success Factors \\
\hline $\begin{array}{l}\text { Holland and Light } \\
\text { (1999) }\end{array}$ & $\begin{array}{l}\text { Strategic: legacy systems, business vision, ERP strategy, top management support, project scheduling and planning. Tactical: } \\
\text { client consultation, software configuration, client acceptance, monitoring and feedback, communication, troubleshooting. }\end{array}$ \\
\hline $\begin{array}{l}\text { Parr and Shanks } \\
(2000)\end{array}$ & $\begin{array}{l}\text { Management support, best people full-time, empowered decision-makers, deliverable dates, champion, vanilla ERP, smaller } \\
\text { scope, definition of scope and goal, balanced team, commitment. }\end{array}$ \\
\hline $\begin{array}{l}\text { Nah, Lau, and } \\
\text { Kuang (2001) }\end{array}$ & $\begin{array}{l}\text { Top management support; business plan and vision; business process re-engineering with minimum customization; project } \\
\text { management; monitoring and evaluation of performance; effective communication; software development, testing, and } \\
\text { trouble-shooting; project champion; appropriate business and IT legacy systems. }\end{array}$ \\
\hline $\begin{array}{l}\text { Somers and Nelson } \\
(2001)\end{array}$ & $\begin{array}{l}\text { Top management support, project champion, user training and education, management of expectations, vendor-customer } \\
\text { partnerships, use of vendor's development tools, careful selection of the appropriate package, project management, } \\
\text { steering committee, use of consultants, minimal customization, data analysis and conversion, business process re-engineering, } \\
\text { defining the architecture, dedicated resources, project team competence, change management, clear goals and objectives, } \\
\text { interdepartmental communication and cooperation, ongoing vendor support. }\end{array}$ \\
\hline $\begin{array}{l}\text { Finney and } \\
\text { Corbett (2007) }\end{array}$ & $\begin{array}{l}\text { Top management commitment and support, visioning and planning, build a test case, project champion, implementation } \\
\text { strategy and timeframe, vanilla ERP, project management, change management, managing cultural change, balanced } \\
\text { team, project team composed of the best and the brightest, communication plan, empowered decision makers, team } \\
\text { morale and motivation, project cost planning and management, BPR and software configuration, legacy system } \\
\text { considerations, IT infrastructure, client consultation, selection of ERP, consultant selection and relationship, training and } \\
\text { job redesign, troubleshooting and crisis management, data conversion and integrity, system testing, post-implementation } \\
\text { evaluation, and analysis of ERP literature. }\end{array}$ \\
\hline $\begin{array}{l}\text { Jayaraman and } \\
\text { Bhatti (2008) }\end{array}$ & $\begin{array}{l}\text { Project management, business process re-engineering, user training and education, technological infrastructure, change and risk } \\
\text { management, top management support, effective communication, balanced team, users' involvement, consultants' involvement, } \\
\text { clear goals and objectives. }\end{array}$ \\
\hline
\end{tabular}

Note. The list is based on the findings on critical success factors from Holland and Light (1999), Parr and Shanks (2000), Nah, Lau, and Kuang (2001), Somers and Nelson (2001), Finney and Corbett (2007), and Jayaraman and Bhatti (2008).

\subsection{Historical Perspective of ERP}

Organizations need to connect the information supplied by each department into a common entity to remain competitive. There is a strong need for a seamless flow of data within and between functional units to increase efficiency in areas such as procurement, distribution of goods and services, managing stocks, and to help decision making. A capability to obtain the right information at the right time can usher enormous benefits to an organization (Rashid, Hossain, \& Patrick, 2002). ERP software systems that emerged in the late 1970s continue to offer large organizations out-of-the-box solutions for complex needs. ERP systems are not projects that someday end; they are a way of life that require a high degree of alignment between business strategies, informational technology strategies, and organizational processes (Davenport, 1998; Esteves \& Pastor, 2001).

\subsection{Defining ERP}

American Production and Inventory Control Society defined ERP as "a method for the effective planning and controlling of all the resources needed to take, make, ship and account for customer orders in a manufacturing, distribution or service company" (Rashid et al., 2002, p.3). Other definitions of ERP include: "One database, one application and a unified interface across the entire enterprise" (Tadjer, 1998); "ERP systems are computer-based systems designed to process an organization's transactions and facilitate integrated and real-time planning, production, and customer response" (O'Leary, 2001). Davenport (1998) illustrated the concept of ERP systems as explained in Figure 1 (Rashid et al., 2002). This concept is still true, with modules such as sales, distribution, and service applications at the front office supporting customers, while inventory, procurement, manufacturing, and finance applications support suppliers at the back office. A central database interacts with both front and 
back offices and with human resources and corporate reporting.

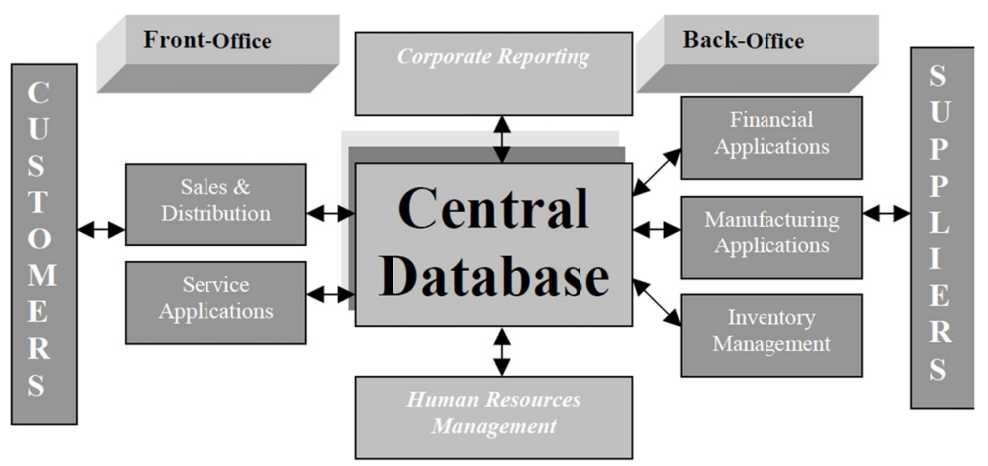

Figure 1. ERP concept

Reprinted from "The Evolution of ERP Systems: A Historical Perspective" by Rashid et al., 2002. Reprinted with permission.

\subsection{Evolution of ERP}

As outlined in Figure 2, and posited by Rashid et al. (2002), inventory control packages, written using programming languages such as COBOL and FORTRAN, were used by organizations in the 1960s for automating systems. In the 1970s, material requirement and planning (MRP) systems were used to plan parts and product requirements within a production process. However, in the 1980s, MRP II was developed to optimize the production process; it added components such as human resources, finance, shop floor, engineering, and distribution. Expanding these concepts, ERP systems appeared in the 1990s, capable of integrating business processes throughout an enterprise (Rashid et al., 2002).

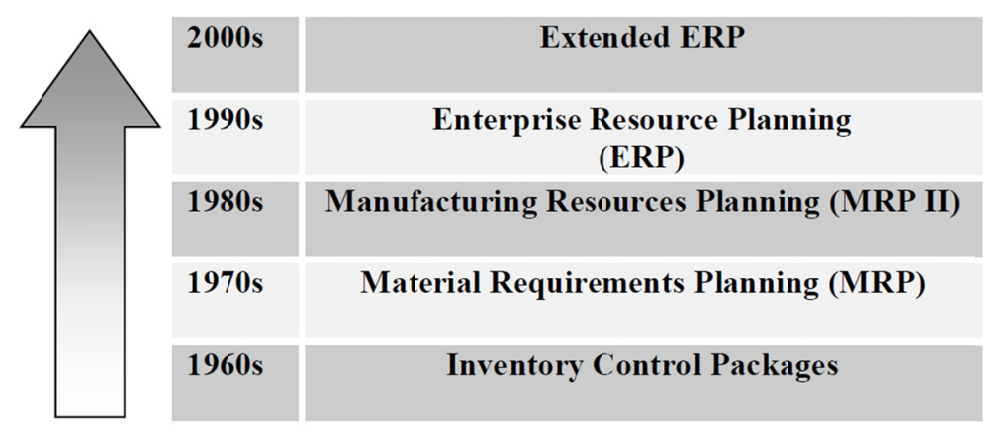

Figure 2. ERP evolution

Reprinted from "The Evolution of ERP Systems: A Historical Perspective" by Rashid et al., 2002. Copyright 2002 by Idea Group Publishing.

There were some significant changes that impacted the use of ERP software in this decade. ERP vendors introduced new functions or add ons, such as customer relationship management (CRM), supplier relationship management (SRM), and advanced planner and optimizer (APO), which resulted in extended ERP in the 2000s. Besides the on-premise ERP solutions, which accounted for 56\% of ERP software used in 2015, ERP diversified into software as service (SaaS) (17\%), and to cloud ERP systems (27\%), which have the capability of hosting and managing from off-site locations (Panorama Consulting, 2016b).

\subsection{Major ERP Systems}

According to the Clash of Titans 2016 report by Panorama Consulting [59], among the major ERP system vendors, SAP has a market share of $23 \%$, followed by Oracle with $16 \%$, Infor with $16 \%$, and Microsoft Dynamics with $9 \%$. Tier II vendors have a total of $12 \%$, and Tier III have a total of $26 \%$ of market share.

SAP. Started by five former IBM employees in 1972, SAP (Systeme, Anwendungen, und Produkte in Datenverarbeitung, or Systems, Applications and Products in Data Processing), leads the ERP market (SAP, 2016; 
Panorama Consulting, 2016a). SAP launched its first ERP software in 1979 as R/2, then redesigned the software in 1992 using client server architecture. The resulting software, R/3, became an instant hit. SAP offers ERP solutions, as described in Figure 3, to all industry segments, including small and midsize businesses. SAP applications run on the technology platform of NetWeaver alongside SAP Business Suite, an integrated application capable of providing industry-specific solutions such as retail, banking, real estate, oil and gas, and aerospace (SAP, 2016; Panorama Consulting, 2016a).

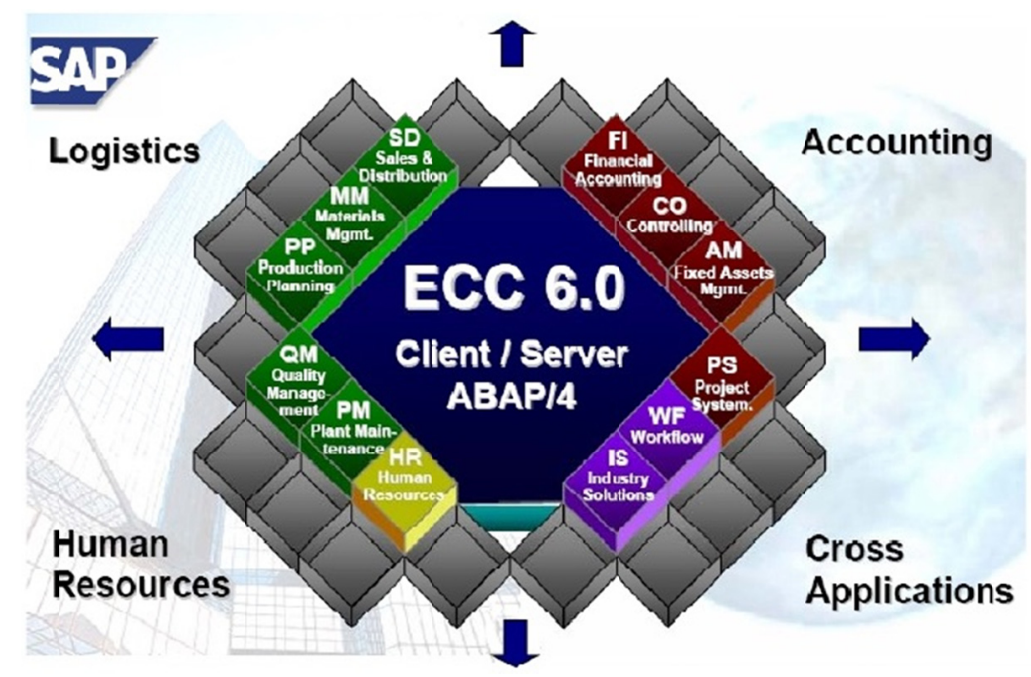

Figure 3. SAP module overview: The list of SAP functional modules

Adopted from http:/www.asugnews.com/article/what-is-sap-simple-logistics-s4hana-enterprise-management\# (ASUG, 2016). Copyright ASUGNews.com. Reprinted with permission.

Oracle. Oracle expanded into the ERP market after the high-profile acquisitions of JD Edwards (JDE), Seibel CRM, and PeopleSoft. Oracle E-Business Suite (EBS) has more than 10 product lines, offering several modules with one single database and supporting a variety of business processes. JDE is an integrated suite that supports the manufacturing industry and uses an open platform. PeopleSoft has a web-centric design, with eight application solutions including financials, supply chain, HR, and CRM. PeopleSoft is ideal for financial and public-sector companies, according to Panorama Consulting (2016a). Oracle EBS has a well-built architecture, a complex pricing module, and strong accounting and finance functionality.

Microsoft Dynamics. In 2000 Microsoft acquired Great Plains, a US accounting package. Microsoft then acquired Navision, a company with its own eponymous accounting and ERP solution and Axtapa, a strong ERP solution with CRM, distribution, and manufacturing capabilities. Microsoft's offerings include Microsoft Dynamics GP, an out-of-the box solution for small and midsize businesses; Microsoft Dynamics NAV, a broader solution for small and midsize businesses; and Microsoft Dynamics AX, for larger businesses with industry-specific solutions and cloud-enabled capabilities in its latest version (Panorama Consulting, 2016a).

\section{Methodology}

The research used a qualitative exploratory single-case study design to understand perceptions of four project role groups about critical challenges in ERP implementation. Exploratory case study research investigates a phenomenon by understanding perceptions and is usually focused on a small sample population to arrive at in-depth and rich data (Hewlett, 2005; Yin, 2014). These case studies typically involve small heterogeneous samples, which offer in-depth investigation. Such a case study is an appropriate tool for undertaking research in ERP implementation (Mishra \& Mishra, 2011; Yin, 2009). Characteristics applicable to exploratory case study research were aligned with this study's objectives: enabling deep focus on scope; generating hypotheses rather than testing them; and exploring a heterogeneous population instead of a homogeneous one (Gerring, 2007). This research also involved collecting documentation and archived records (Denzin, 2012; Howe, 2012; Nickson, 2014).

The case setting used for the current study is a Canadian oil and gas company involved in ERP implementation. 
Three oil companies in Canada were identified as having integrated refining capabilities such as upstream, downstream, and retail business capabilities. All three had significant staff size and ERP implementation project history. For general guidance toward site selection, examples were drawn from the literature (Mishra \& Mishra, 2011). These organizations typically employed more than 5000 employees, and each has a good IT presence. The inclusion criteria required that participants have experience in ERP project roles and have worked in ERP implementation projects in the Canadian oil and gas industry. One of these three companies agreed to participate in the study and helped solicit employee participation; however, participants were selected based on inclusion criteria and on a first-response basis.

\subsection{Data Collection}

Stratified sampling was used due to the small sample size and the desire to obtain data from each stratum or participant group (Gerring, 2007). Twenty participants were selected using stratified purposive sampling from the chosen company. The sample represents four participant project team roles that consisted of three senior leaders, four project managers, six project team members, and seven business users, for a total of 20 subjects. Noted characteristics that were not used for selection criteria included project-team member age level, overall employment experience, and educational level. McLeod (2010) advocates for participants to be knowledgeable about the phenomenon in its context, which was required for participant inclusion in this study. The draft interview guide questions were compiled based on research for the current study. The research was field-tested using subject matter experts (SMEs) and role-players. All interviews were held in a public place and further document review facilitated data triangulation, which provided another source of data beyond the semi-structured interviews (Denzin, 2012; Howe, 2012; Nickson, 2014; Yin, 2009).

\subsection{Data Analysis}

The researcher conducted a total of 20 face-to-face interviews with participants from the four project team role groups. In-person interviews were voice-recorded, and audio files were transcribed. The collected data was entered in NVivo software for data coding and analysis and data analysis was conducted. Further, document review facilitated data triangulation such that it provided another source of data (Denzin, 2012; Jonsen \& Jehn, 2009; Yin, 2009).

\section{Discussion of Results}

The research study generated 60 critical challenges, as described in Appendix A. Based on highest frequency count across the four groups, 12 challenges emerged as listed in Table 3, Figure 4. Disbanding the project team very quickly after implementation was the most important challenge (identified by six, or $30 \%$, of participants), followed by interface issues, lack of proper testing, time zone limitations, stress, offshoring, people's resistance to change, a short hyper-care period, data cleansing, excessive customization, and leadership that didn't understand the complexities.

Based on demographic information, respondents from the senior leader and project manager groups had an average experience of 22 years in the organization; project team members had 14 years; and members of the business user group had 20 and a half years of total experience in the organization. Triangulation of responses showed that all four groups responded to the critical challenges in ERP. The generation of this large list of 60 critical challenges (Appendix A) was the result of this response from the participants. The researcher also analyzed all 60 challenges for future research not discussed in current literature. The four groups were overwhelmingly certain about the existence of critical challenges and maintained that these challenges were significant. However, senior leader and project manager role groups did not respond with the critical challenges of stress on people, interface issues, and quick disbandment of the project team; the researcher did not anticipate this omission from these role groups. 
Table 3. Critical Challenges in ERP implementation as reported by project role groups

\begin{tabular}{lllll}
\hline Critical Challenges: Top Themes & Senior Leader & $\begin{array}{l}\text { Project } \\
\text { Manager }\end{array}$ & $\begin{array}{l}\text { Project } \\
\text { Team } \\
\text { Member }\end{array}$ & $\begin{array}{l}\text { Business } \\
\text { User }\end{array}$ \\
\hline Project team was disbanded very quickly & - & - & 4 & 2 \\
Interface issues & - & - & - & 5 \\
No proper testing & - & 1 & 3 & 1 \\
Time zone limitations & - & 2 & - & 3 \\
Implementation causes stress on people & - & - & 3 & 1 \\
Offshoring causes delays & - & 1 & - & 3 \\
People are resistant to change & 1 & - & 1 & 2 \\
Short hyper-care support period & 1 & - & 2 & 1 \\
Lack of business buy-in from internal stakeholders & - & 1 & 2 & 1 \\
Data cleanse & - & 1 & 1 & 1 \\
Excessive customization is sub-optimal & 1 & - & 2 & - \\
Leadership didn't understand the complexities & - & 1 & 2 & - \\
Total & 3 & 7 & 20 & 20 \\
\hline
\end{tabular}

Note. The table highlights the top 12 critical challenges encountered by the case organization during ERP implementation. This is based on a high-frequency count across all four project role groups. A dash indicates that no member of the group reported that critical challenge.

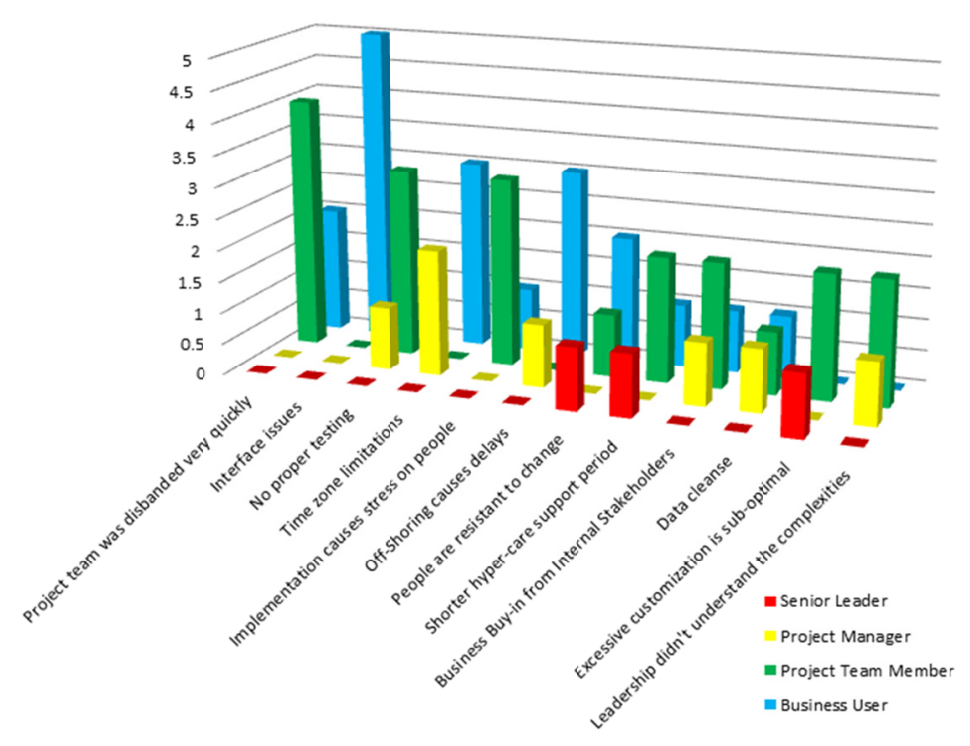

Figure 4. Critical challenges in ERP implementation, as answered by the four project role groups.

Furthermore, the researcher was surprised by the extent to which all four ERP project role groups identified the critical challenges. Out of 60 challenges, 29 had two or more participant responses, and 31 challenges had only one response. Although the current study highlighted only the top 12 challenges, the resiearch identified a large number of responses about critical challenges across all role groups, particularly the project team member and business user groups. The top 12 critical challenges identified from interview responses are:

\subsection{Project Team Was Disbanded very Quickly}

Quick disbandment of the project team means that soon after the project went live, consultants left, and employees had to find new roles within the company, eventually losing all knowledge. One comment from a business user epitomizes the challenge: "It was extremely high pressure. We lost a few players. I remember on one morning at a meeting, we were missing out of ten, we were missing three persons." One team member commented, "I think one other challenge that we felt down the road, was how quickly the project team basically disbanded after [go-live]." Another team member was critical: 
At go-live, I think the fact that the deploy teams disappeared so quickly was a huge challenge because so many things were going wrong, and it was just kind of the business left to deal with it.

One team member explained this concept well:

Shortly after the project [was] rolled out, the project teams were dismantled [and] they lost all this knowledge, right. So the consultants were gone, the people who rolled out on the project, the company employees who had done other roles or couldn't succeed in finding other roles, so you lost all this knowledge.

\subsection{Interface Issues}

The challenge around interface issues (Yen \& Sheu, 2004) was raised by several business users. One remarked, "there were some system interfaces that didn't work as expected even after all that testing [and] there were some interfaces that just didn't do what we expected [of] them." Another commented: "so we had all those things designed like as model [interfacing with SAP, connected applications, terminal systems], we took part of it, so how to fit in was difficult." Another business user clarified that "there were some system interfaces that didn't work as expected even after all that testing. There were some interfaces that just didn't do what we expected them to do." Yet another business user said: "the challenges were interfacing; interfacing like [multiple systems], and interfacing [was] a big, big issue."

\subsection{No Proper Testing}

Lack of proper testing during implementation was another frequently mentioned critical challenge (Finney \& Corbett, 2007; Nah et al., 2001). Five participants gave examples such as that there was no regression testing, no flexibility to include additional test cycles, and that scenarios were tested and passed without correct data. A project team member explained, "We had a hard time getting our testing done properly because of issues, data not converted yet." Another team member said:

that's far [sic] is the biggest piece is just being so inclusive, um, and that's where the standard structure sort of in my mind failed us a little bit, well. There wasn't the flexibility to include additional test cycles or additional test scripts though we did that as much as possible.

\subsection{Time Zone Limitations}

Another critical challenge was time-zone limitations. One project manager stressed that: "time was another specific challenge which we hadn't encountered in previous countries really, there are six different time zones here [in Canada], so you are going live six times per se, [and] that was new for Canada [the case organization]." These limitations can be a critical challenge in ERP implementations taking place in an area encompassing multiple time zones.

\subsection{Implementation Causes Stress}

Another critical challenge raised is that implementation causes stress on people. One team member said: "But I feel there was something lacking where people didn't, I don't know, it was stress, was definitely stress-related, people were stressed out, you know we were in short, you know, timeframe we had to get it done."

Another team member explained:

I think there was there was too much pressure to want to show that you were meeting the targets and on track and the worry that red is bad and that; I mean, red means you failed, whereas red should really be used as, you know, to show that okay there's an issue here we need to deal with.

\subsection{Offshoring Causes Delays}

How work was handled from offshore and the associated delays was another critical challenge mentioned by several participants. One project manager stated: "we had to reorganize hand-offs to offshore, [and this] was a challenge."

One of the business users explained:

In the beginning, it was even worse because we had to do a part send it [sic] to [one Asian country], and they send it to [a second country], back to [first country], so it could take like two days.

\subsection{People Are Resistant to Change}

People resisting change is another highlighted critical challenge (Finney \& Corbett, 2007; Kemp \& Low, 2008; Somers \& Nelson, 2001). One senior leader explained "initial resistance [to change], why do we want to do this, why do we want to allow ourselves to become distracted with, you know, with this type of activity the business is enjoining," ... "because you know how people are, they resist change". Some business users, which are also 
project stakeholders, felt that workers resisted change. One business stated:

I think the biggest challenge is people, people absolutely. People are resistant to change. They're good at their jobs and it's uncomfortable to be doing something new. So I think the initial reaction is oh no, I don't like this system, it's no good. Sometimes they haven't been into the system yet, and they've decided the system's no good.

One of the senior leaders emphasized:

[Challenge] we encountered, I would characterize as organizational, so, that initial resistance, why do we want to do this, why do we want to allow ourselves to become distracted with, you know, with this type of activity.

\subsection{Short Hyper-Care Support Period}

Business users, senior leaders, and team members all criticized the reduced brief hyper-care period after go-live to support the business. One team member's perspective was:

We let go of everybody very quickly, within 6 weeks everybody was gone. So between, I think it was 4 to 6 weeks, we were so worried about the cost of the implementation, we got rid of everybody who had any knowledge. Before we really understood there was an issue, because we only had really, we had even went through a full month yet [sic] to really understand [the impact].

One team member said, "we were so worried about the cost of the implementation, we got rid of everybody who had any knowledge." Another said, "I would have done a lot longer hyper-care period, so, it would have been probably a minimum six months; six months to a year."

\subsection{Lack of Business Buy-In from Internal Stakeholders}

One team member stated, "When you start impacting people the way they worked, you know these are key people in key roles so if they are not on board and if they are not supportive, it's going to be a huge barrier." Another added, "I think some of the challenges that I can think of [sic] is getting the buy-in from the business." The users argued that "if the current system is working, why do we need to move to another ERP?" However, one project manager said: "ensuring that you keep your stakeholders, laid out all the benefits, [and] that's to me is the biggest challenge is to get buy-in from the end users to a new system."

\subsection{Data Cleanse}

The importance of "data cleanse" as a critical challenge (Doom et al., 2010; Finney \& Corbett, 2007; Somers \& Nelson, 2001) was underscored by a project manager's response: "part of the challenge was understanding how the system works in a lot of detail, [and] if you don't do that properly and you don't educate the business, it is very hard for them to cleanse." Except for senior leaders, members of all groups stressed the importance of data cleansing. One business user emphasized, "it is hard to actually articulate in some ways, but the data cleanse [is] really, really important."

\subsection{Excessive Customization Is Sub-Optimal}

Several participants stated that excessive customization is sub-optimal (Momoh et al., 2010; Themistocleus et al., 2001). One team member explained, "where you are heavily customized because then [sic] they can really take lot of run maintain costs and individual specific skill sets that you need to be able to support."

Another team member said:

[When] you are heavily [excessively] customized, because then they can really take lot of run maintain costs and individual specific skill sets that you need to be able to support, so I think you can take out-of-the-box install and minimize customization as much as possible.

\subsection{Leadership Didn't Understand the Complexities}

One project manager observed:

I think going in to the process early on, the leadership had assumed that Canada would be a very simple solution. So of course they missed really understanding the complexities that were involved.

One team member said, "leaders don't have a good understanding [and] sometimes complexity involves in [sic] some of the implementations [which] underestimate the efforts, and then it puts pressure on the people and on the team, [which] is also demotivating."

Response triangulation showed that all groups had critical challenges. The participants' responses generated 60 critical challenges (Appendix A). Out of these, an analysis of the top 12 challenges (Table 3; Figure 4) indicated that both project team members and business users ( $77 \%$ in total) overwhelmingly discussed them all. Senior 
leaders and project managers discussed the remaining 33\% (three and seven challenges, respectively). The findings show that the groups' responses give perspective to challenges both before and after implementation and therefore are valid. The ERP implementation at the research site was similar in size and depth to that of any other large organization. With the strength and experience the organization had in similar country rollouts, this large number of critical challenges is a cause for concern. The seven new challenges identified from the top 12 responses not discussed in the literature are: (a) project team disbanded very quickly, (b) time zone limitations, (c) lack of business buy-in from internal stakeholders, (d) implementation causes stress, (e) offshoring causes delays, (f) short hyper-care support period, and (g) leadership didn't understand the complexities. Among the critical challenges identified from participant responses, any challenges missing from the existing literature should be part of any future study.

\subsection{Significance of Critical Challenges}

Eighteen out of 20 participants (90\%) across all groups overwhelmingly indicated that the critical challenges were significant during ERP implementation. Only one project manager participant and one project team member argued that critical challenges were not significant (Table 4; Figure 5). All groups were overwhelmingly certain about the existence of critical challenges and maintained that these challenges were significant during ERP implementation.

Table 4. Significance of critical challenges as reported by members of the project role groups

\begin{tabular}{lllll}
\hline Significance of challenges & Senior Leader & $\begin{array}{l}\text { Project } \\
\text { Manager }\end{array}$ & $\begin{array}{l}\text { Project } \\
\text { Team } \\
\text { Member }\end{array}$ & $\begin{array}{l}\text { Business } \\
\text { User }\end{array}$ \\
\hline Significant & & 3 & 5 & 7 \\
Not Significant & 3 & 1 & 1 & - \\
Total & - & 4 & 6 & 7 \\
\hline
\end{tabular}

Note. The table highlights the significance of critical challenges during ERP implementation. This is based on high-frequency count across all four project role groups. A dash indicates that no member of the group reported that critical challenge as significant.

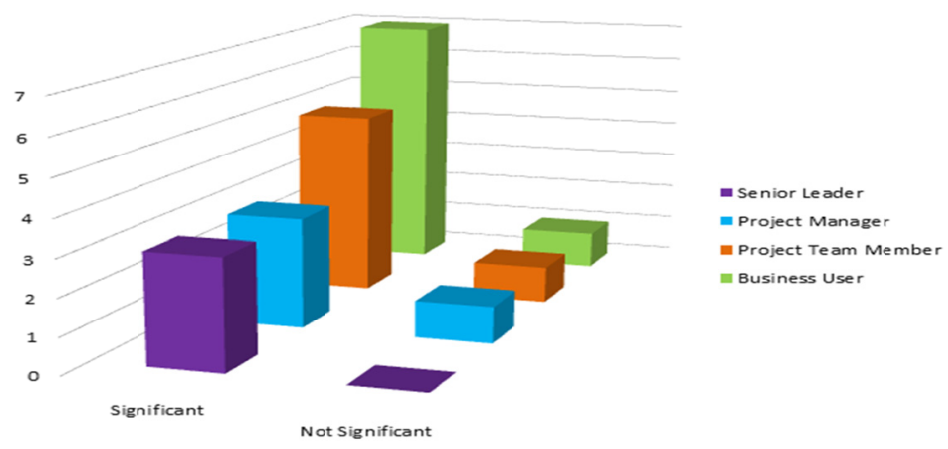

Figure 5. How significant critical challenges were, as answered by the members of the four project role groups

The responses highlighted significant challenges encountered during ERP implementation (Momoh et al., 2010; Peci \& Važan, 2014; Sar \& Garg, 2012; Shaul \& Tauber, 2013; Stanciu \& Tinca, 2013; Yazdi \& Salajegheh, 2011). While looking at the triangulation, only $10 \%$ (two out of 20) argued that the critical challenges were insignificant overall. However, both these participants did respond with explicit critical challenges during their interviews. When looking at the triangulation, all four groups displayed an equal degree of confidence regarding the significance of critical challenges. Addressing this organization's critical challenges provides increased visibility into the problems faced by organizations during implementations (Momoh et al., 2010; Mishra \& Mishra, 2011; Stanciu \& Tinca, 2013). Also, correcting critical challenges, which represent failure factors as opposed to success factors, can ensure better project performance and project success (Kimberling, 2011; Momoh et al., 2010; Stanciu \& Tinca, 2013; Shaul \& Tauber, 2013). 


\section{Implications and Limitations}

One of the major implications is that the critical challenges in this ERP study are related to the Canadian oil and gas industry. The case organization chosen was a global oil and gas company with strong regional presence in the local Canadian market. The critical challenges generated based on the responses from the project role groups belonging to the case organization highlighted the significance of the study. In particular, Mishra and Mishra (2011) pointed out that one of the main challenges specific to oil and gas is that the design, development, testing, and building of such complex interfaces are time-consuming (Smith, Meade, Wolf, \& Song, 2013; Yen \& Sheu, 2004). One of the significant challenges among the top 12 was interface issues, which highlighted this critical challenge in the oil and gas industry.

Another implication is that critical challenges were significant during the ERP implementation (Table 4; Figure 5). $90 \%$ of responses from all project role groups clearly indicated that the critical challenges were significant during ERP implementation. There was minimal difference to this viewpoint during triangulation, with only $10 \%$ (two out of 20) arguing that the critical challenges were not significant. However, both these participants had responded strongly to critical challenges during the interview. Also, all four participant project role groups evenly pointed out the significance of critical challenges.

The third implication of the study is that, although theories other than complexity theory were not part of the study's theoretical framework, the study findings specifically considering the critical challenges of people's resistance to change, lack of business buy-in from stakeholders, and interface issues suggest that there may be implications to the theories of system and change management (Buckle Henning \& Chen, 2012; Kotter, 2012; Lucas, 2005; Malek \& Yazdanifard, 2012; Poti, Bhattacharyya, \& Kamalanabhan, 2010; Tambovcevs \& Merkuryev, 2009).

Although the selected sample size was appropriate and within norms, the sample size was not significant enough that study population findings can be generalized (Marshal, Cardon, Poddar, \& Fontenot, 2013; Yin, 2011). If the study were to be replicated, it would necessary to avoid having a general senior leader group and instead add a business leader group, and an IT leader group to get senior leadership perspective from both business and IT. Participant's time constraint is another limitation to this exploratory single case study. Some interviewees have to rush to other appointments to accommodate daily engagements, which may have affected data collected. Another study limitation is the utilization of semi-structured questionnaire used as the main instrument for collecting data. Although participants were able to share their perceptions, they may have been unwilling to fully express their experiences as the researcher has to rely on participant honesty, which may have affected the depth of the study (Gerring, 2007).

\section{Future Study}

This study was conducted in a case organization that implemented SAP as its ERP system. Therefore, a similar study should use another major ERP system, such as Microsoft Dynamics ERP or Oracle ERP. By gaining the perspective of a similar implementation in the oil and gas industry using another major ERP system, the new study could offer similarities and differences as compared with SAP project implementation results.

The second recommendation is to conduct a quantitative study using the list of the top 12 critical challenges (Table 3; Figure 4) as well as the full list of 60 challenges (Appendix A), many of which are missing from the existing literature. By doing so, these critical challenges could be correlated to other industries; it would also be possible to establish correlations between project performance and critical challenges during ERP implementation. Also, using such a quantitative, descriptive, non-experimental design and using a survey method, it would be possible to validate many responses in senior leader, project manager, project team member, and business user groups across multiple organizations to support the findings from the current study (Denzin \& Lincoln, 2008). Another recommendation is to conduct a multiple-case study. This could employ two or more organizations so that contrasting or similar results could be predicted (Yin, 2014). By repeating or replicating this study, results from the present study could then be compared with the results from multiple cases within each setting and across settings (Yin, 2014).

\section{Conclusion}

Addressing critical challenges in an ERP implementation can provide increased visibility of the problems faced by organizations (Momoh et al., 2010; Mishra \& Mishra, 2011; Stanciu \& Tinca, 2013). Correcting critical challenges, which represent failure factors as opposed to success factors, can ensure better project performance and success (Kimberling, 2011; Momoh et al., 2010; Stanciu \& Tinca, 2013; Shaul \& Tauber, 2013). The literature has identified critical challenges based on several studies (Ehie \& Madsen, 2005, Momoh et al., 2010). However, no 
comprehensive list of challenges has been compiled for the use of organizations undertaking ERP implementation. Specifically, the current study explored critical challenges method and compiled a comprehensive list of critical challenges that can affect an ERP implementation. Therefore, organizations undertaking future implementations can review the full list of critical challenges, which can be added to the body of knowledge.

\section{References}

ASUG. (2016). SAP module overview: List of SAP functional modules. Retrieved from http://www.asugnews.com/article/what-is-sap-simple-logistics-s4hana-enterprise-management\#

Buckle Henning, P., \& Chen, W. C. (2012). Systems thinking: Common ground or untapped territory? Systems Research and Behavioral Science, 29(5), 470-483.

Davenport, T. H. (1998). Putting the enterprise into the enterprise system. Harvard Business Review, 76(4), $121-131$.

Denzin, N. (2012). Triangulation 2.0. Journal of Mixed Methods Research, 6(2), 80-88. https://doi.org/10.1177/1558689812437186

Denzin, N. K., \& Lincoln, Y. S. (2008). Strategies of qualitative inquiry (3rd ed.). Thousand Oaks, CA: Sage.

Doom, C., Milis, K., Poelmans, S., \& Bloemen, E. (2010). Critical success factors for ERP implementations in Belgian SMEs. Journal of Enterprise Information Management, 23(3), 378-406. https://doi.org/10.1108/17410391011036120

Ehie, I. C., \& Madsen, M. (2005). Identifying critical issues in enterprise resource planning (ERP) implementation. Computers in Industry, 56(6), 545-557. https://doi.org/10.1016/j.compind.2005.02.006

Erkan, T. E., \& Rouyendegh, B. D. (2012). ERP business productivity evaluation by using multi-criteria decision making among end users in Turkish manufacturing Industry. 2nd World conference on Information Technology (WCIT-2011) AWER Procedia, 1, 245-249.

Esteves, J, M., \& Pastor J. A. (2001). Analysis of critical success factors relevance along SAP implementation phases. Proceedings of Seventh Americas Conference on Information Systems, USA. Retrieved from $\mathrm{http} / / /$ aisel.aisnet.org/cgi/viewcontent.cgi?article=1636\&context=amcis2001

Finney, S., \& Corbett, M. (2007). ERP implementation: A compilation and analysis of critical success factors. Business Process Management Journal, 13(3), 329 -347. https://doi.org/10.1108/14637150710752272

Gartner (2011) Market share analysis: ERP software, worldwide, 2011. Stamford, Connecticut: Gartner

Gerring, J. (2007). Case study research: Principles and practices (1st ed.). Cambridge, UK: Cambridge University.

Hewlett, A. K. (2005). Constructive thinking from theory to practice: An exploratory study (Doctoral dissertation). Retrieved from ProQuest Dissertations and Theses database. (UMI No. NR08783)

Holland, P.C., \& Light, B. (1999). A critical success factors model for ERP implementation. IEEE Software, 3(16), 30-36. https://doi.org/10.1109/52.765784

Howe, K. (2012). Mixed methods, triangulation, and causal explanation. Journal of Mixed Methods Research, 6, 89-96. https://doi.org/10.1177/1558689812437187

Jayaraman, V., \& Bhatti, T. (2008). The critical success factors for the acquisition and implementation of ERP systems. Paper presented at the International DSI / Asia and Pacific DSI 2007, Bangkok, Thailand. Retrieved from http://iceb.nccu.edu.tw/proceedings/APDSI/2007/papers/Final_27.pdf

Jonsen, K., \& Jehn, K. A. (2009). Using triangulation to validate themes in qualitative studies. Qualitative Research in Organizations and Management: An International Journal, 4, 123-150. https://doi.org/10.1108/17465640910978391

Kemp, M., \& Low, G. (2008). ERP innovation implementation model incorporating change management. Business Process Management Journal, 14, 228-242. https://doi.org/10.1108/14637150810864952

Kimberling, E. (2011). 2011 ERP Report: ERP implementation project costs and durations down, business benefits up. Denver, CO: Panorama Consulting. Retrieved from http://panorama-consulting.com/2011-erp-report-erp-implementation-project-costs-and-durations-down-bus iness-benefits-up/

Kotter, P. J. (2012). Kotter Change Management Model. Retrieved from 
https://strategicsourcing.gov/sites/default/files/uploads/guiding_principles_for_leading_chang e_guide_vjune2012.pdf

Laukkanen, S., Sarpola, S., \& Hallikainen, P. (2007). Enterprise size matters: Objectives and constraints of ERP adoption. Journal of Enterprise Information Management, 20, 319-334. https://doi.org/10.1108/17410390710740763

Loo, R. (2003). A multi-level causal model for best practices in project management. Benchmarking: An International Journal, 10, 29-36. https://doi.org/10.1108/14635770310457520

Lucas, C. (2005, February 3). The philosophy of complexity. Retrieved from http://pssc.wdfiles.com/local--files/the-philosophy-of-complexity/A-filosofia-da-complexidade.pdf

Malek, R., \& Yazdanifard, R. (2012). Overview of change management and its implementation. Business, Economics, Financial Sciences, and Management, 149-153. https://doi.org/10.1007/978-3-642-27966-9_21

Marshall, B., Cardon, P., Poddar, A., \& Fontenot, R. (2013). Does sample size matter in qualitative research?: A review of qualitative interviews in IS research. Journal of Computer Information Systems, 54(1), 11-22. Retrieved from http://iacis.org/jcis/articles/JCIS54-2.pdf

McLeod, J. (2010). Case study research in counseling and psychotherapy. Thousand Oaks, CA: Sage.

Mishra, A., \& Mishra, D. (2011). ERP System implementation: Evidence from the oil and gas sector. Acta Polytechnica Hungarica, 8(4), 416-428.

Momoh, A., Roy, R., \& Shehab, E. (2010). Challenges in enterprise resource planning implementation: State-ofthe-art. Business Process Management Journal, 4, 537-565. https://doi.org/10.1108/14637151011065919

Motwani, J., Subramanian, R., \& Gopalakrishna, P. (2005). Critical factors for successful ERP implementation: Exploratory findings from four case studies. Computers in Industry, 56, 529-544. https://doi.org/10.1016/j.compind.2005.02.005

Nah, F. F., Lau, J. L., \& Kuang, J. (2001). Critical factors for successful implementation of enterprise systems. Business Process Management Journal, 7, 285-296. https://doi.org/10.1108/14637150110392782

Nickson, A. (2014). A qualitative case study exploring the nature of new managerialism in UK higher education and its impact on individual academics' experience of doing research. Journal of Research Administration, 45(1), 47-80.

O'Leary, D. E. (2000). Enterprise resource planning systems: Systems, life cycle, electronic commerce, and risk. Cambridge, UK: Cambridge University.

Panorama Consulting (2016a). Clash of the Titans 2016: SAP vs. Oracle vs. Microsoft Dynamics vs. Infor. Retrieved

from http://panorama-consulting.com/resource-center/clash-of-the-titans-2016-sap-vs-oracle-vs-microsoft-dynam ics-vs-infor/

Panorama Consulting (2016b). 2016 ERP report. Retrieved from http://panorama-consulting.com/resource-center/2016-erp-report/

Parr, A., \& Shanks, G. (2000). A model of ERP project implementation. Journal of information technology, 15(4), 289-303

Peci, M., \& Važan, P. (2014). The biggest critical failure factors in ERP implementation. Applied Mechanics and Materials, 1476-1480. https://doi.org/10.4028/www.scientific.net/amm.519-520.1476

Poti, S., Bhattacharyya, S., \& Kamalanabhan, T. (2010). Change processes and its impact on individuals: Perception of ERP users in India. International Journal of Information Systems and Change Management IJISCM, 4(4), 275. https://doi.org/10.1504/ijiscm.2010.036913

Project Management Institute (PMI). (2013). A guide to the project management body of knowledge. Newtown Square, PA: PMI.

Project Management Institute (PMI). (2014), Navigating complexity: A practice guide. Newtown Square, PA: PMI.

Rashid, M. A., Hossain, L., \& Patrick, J. D. (2002). The evolution of ERP systems. Enterprise Resource Planning: Global Opportunities and Challenges, 1-16. doi:10.4018/978-1-931777-06-3.ch001

Rockart, J. F. (1979). Chief executives define their own needs. Harvard Business Review, 81-93. 
Sar, A., \& Garg, P. (2012). Analysis of critical failure factors in ERP implementation: An Indian experience. IJBIS International Journal of Business Information Systems, $11, \quad 360$. https://doi.org/10.1504/ijbis.2012.049571

Shaul, L., \& Tauber, D. (2013). Critical success factors in enterprise resource planning systems. ACM Computing Surveys, 45(4), 1-39. https://doi.org/10.1145/2501654.2501669

Smith, A., Meade, M., Wolf, D., \& Song, J. (2013). The CSFs, quality governance, BPR performance and gaining competitive advantage. International Journal of Business and Management, 8(24). https://doi.org/10.5539/ijbm.v8n24p48

Somers, T.M., \& Nelson, K. (2001). The impact of critical success factors across the stages of enterprise resource and planning implementations. Proceedings of the 34th Hawaii International Conference on System Sciences, USA, 105, 1-10. https://doi.org/10.1109/HICSS.2001.927129

Stanciu, V., \& Tinca, A. (2013). ERP solutions between success and failure. Accounting \& Management Information Systems, 12(4), 626-649.

Sumner, M. (2000). Risk factors in enterprise-wide/ERP projects. Journal of Information Technology, 15(4), 317-327. https://doi.org/10.1080/02683960010009079

Tadjer, R. (1998). Enterprise Resource Planning. Internet Week, Manhasset.

Tambovcevs, A., \& Merkuryev, Y. (2009). Analysis of ERP systems implementation in the construction enterprises. Scientific Journal of Riga Technical University. Computer Sciences, 39. https://doi.org/10.2478/v10143-010-0002-1

Tarn, J.M., Yen, D.C., \& Beaumont, M. (2002). Exploring the rationales for ERP and SCM integration. Industrial Management \& Data Systems, 102(1), 26-34.

Themistocleus, M., Irani, Z., O’Keefe, R.M. and Paul, R. (2001). ERP problems and application integration issues: An empirical survey. IEEE Proceedings of the 34th Hawaii International Conference on System Sciences, USA.

Woo, H.S. (2007). Critical success factors for implementing ERP: The case of a Chinese electronics manufacturer. Journal of Manufacturing Technology Management, 18(4), 431-42.

Yen, H. R., Sheu, C. (2004) Aligning ERP implementation with competitive priorities of manufacturing firms: An exploratory study. International Journal of Production Economics, 92, 207-220.

Yin, R. K. (2009). Case study research: Design and methods (4th ed.). Thousand Oaks, CA: Sage.

Yin, R. K. (2011). Applications of case study research. Thousand Oaks, CA: Sage.

Yin, R. K. (2014). Case study research: Design and methods (5th ed.). Los Angeles, CA: Sage. 
Appendix A. Full List of Critical Challenges in ERP Implementation

\begin{tabular}{|c|c|c|c|c|}
\hline Critical Challenges in ERP & $\begin{array}{l}\text { Senior } \\
\text { Leader }\end{array}$ & $\begin{array}{l}\text { Project } \\
\text { Manager }\end{array}$ & $\begin{array}{l}\text { Project Team } \\
\text { Member }\end{array}$ & $\begin{array}{l}\text { Business } \\
\text { User }\end{array}$ \\
\hline Bad feelings about how employees were dealt with & - & - & 1 & - \\
\hline Change management & 1 & - & 1 & - \\
\hline Change request controls are very strict & - & - & - & 1 \\
\hline Changes to strategy and direction & 1 & - & - & - \\
\hline Communication & - & 1 & 1 & - \\
\hline Consultants did not share knowledge & - & - & 1 & - \\
\hline Consultants lack of knowledge of other systems & - & - & 1 & - \\
\hline Cultural differences & - & 2 & - & 1 \\
\hline Data cleanse & - & 1 & 1 & 1 \\
\hline Data migration across different systems & - & - & 0 & 1 \\
\hline Data quality issues & - & - & 1 & 1 \\
\hline Data readiness & - & - & 2 & - \\
\hline Data validation without understanding the data & 1 & - & - & 1 \\
\hline Engagement with users didn't provide a whole lot of detail & - & - & - & 1 \\
\hline Ensuring external stakeholders are aware of the change & - & 1 & - & - \\
\hline ERP implementations are not cheap & 1 & - & - & - \\
\hline Excessive customization is sub-optimal & 1 & - & 2 & - \\
\hline Implementation causes stress on people & - & - & 3 & 1 \\
\hline Inconsistent KPI reporting across the organization & - & 1 & 1 & - \\
\hline Interface issues & - & - & - & 5 \\
\hline Issues after go-live were like a tsunami & - & - & - & 1 \\
\hline Lack of access to people who know the information & - & - & 1 & 1 \\
\hline Lack of access to the system & 1 & - & - & 1 \\
\hline Lack of business ownership & - & 1 & 1 & - \\
\hline Lack of business buy-in from internal stakeholders & - & 1 & 2 & 1 \\
\hline Lack of experienced subject matter experts & 2 & - & - & - \\
\hline Lack of integrated testing \& real live simulations & - & - & 2 & - \\
\hline Lack of integration & - & - & 1 & - \\
\hline Lack of resources & - & - & 1 & - \\
\hline Lack of training & 1 & - & - & 1 \\
\hline Lack of understanding of business requirements & - & - & 1 & - \\
\hline Leader has to champion stability & - & - & - & 1 \\
\hline Leadership changes during project & 1 & - & - & - \\
\hline Leadership commitment to the standard global template was lacking & 1 & - & - & - \\
\hline Leadership didn't understand the complexities & - & 1 & 2 & - \\
\hline Learning new system was challenging to end users & - & - & - & 2 \\
\hline Local management didn't pull the right people & - & - & - & 1 \\
\hline Management did not want to hear bad news & - & - & - & 1 \\
\hline Manual interventions & 1 & - & - & 1 \\
\hline Massive re-organization before an ERP implementation & 1 & - & - & - \\
\hline Misunderstanding of scope & - & - & 1 & - \\
\hline No accountability or checks in place to get the right data & - & - & - & 1 \\
\hline No knowledge transfer from project team to business & 1 & - & - & - \\
\hline No proper testing & - & 1 & 3 & 1 \\
\hline Offshoring causes delays & - & 1 & - & 3 \\
\hline People are resistant to change & 1 & - & 1 & 2 \\
\hline People are not working towards the same goal & - & - & 1 & - \\
\hline Perception that new system should behave like old system & 1 & - & - & - \\
\hline Personality issues & - & - & 1 & - \\
\hline Pressure to be "green" on the dashboards & - & - & 1 & - \\
\hline Project team was disbanded very quickly & - & - & 4 & 2 \\
\hline Project was too long & 1 & - & 1 & - \\
\hline Respecting no-fly zone & - & - & - & 1 \\
\hline
\end{tabular}




\begin{tabular}{|c|c|c|c|c|}
\hline Short hyper-care support period & 1 & - & 2 & 1 \\
\hline Thin line on budget & - & 1 & - & - \\
\hline Time zone limitations & - & 2 & - & 3 \\
\hline Took long time to address the backlog & - & - & - & 1 \\
\hline Unable to deploy resources back to business & - & 1 & 2 & - \\
\hline Use of too many templates & - & - & - & 1 \\
\hline Zero experience with SAP & 1 & - & - & - \\
\hline Total & 19 & 15 & 43 & 40 \\
\hline
\end{tabular}

Note. The table shows 60 critical challenges encountered by the case organization during ERP implementation. This is based on high-frequency count across all role groups. A dash indicates that no group member reported the critical challenge.

\section{Copyrights}

Copyright for this article is retained by the author(s), with first publication rights granted to the journal.

This is an open-access article distributed under the terms and conditions of the Creative Commons Attribution license (http://creativecommons.org/licenses/by/4.0/). 